\title{
Candida guilliermondii AS THE AETIOLOGY OF CANDIDOSIS
}

\author{
Alessandro Comarú PASQUAlotTO(1), Ana Graciela Ventura ANTUNES(2) \& Luiz Carlos SEVERO(2)
}

\begin{abstract}
SUMMARY
Candida guilliermondii is one of the components of human microbiota. This yeast has been infrequently associated with human infections, which may be related to its low pathogenicity. The aim of this study was to provide clinical and epidemiological data for patients infected with C. guilliermondii at Santa Casa Complexo Hospitalar, Brazil. From October 1997 to October 2003, C. guilliermondii was isolated from clinical samples from 11 patients. Three patients were excluded because the isolation of the yeast represented colonisation. Specimens from the eight patients included in the study corresponded to blood $(n=5)$, ascitis fluid $(\mathrm{n}=2)$, and oesophagus biopsy $(\mathrm{n}=1)$. Three patients $(37.5 \%)$ had major immunosuppressed conditions, including solid organ transplantation, AIDS, and leukaemia. Previous use of antibiotics occurred in $87.5 \%$. Main invasive medical procedures were central venous catheter (50.0\%), abdominal surgery (25.0\%), and peritoneal dialysis (50.0\%). No susceptibility data was obtained. Although risk factors for candidaemia were similar amongst patients infected by with C. guilliermondii or other Candida species, mortality associated with $C$. guilliermondii was significantly lower.
\end{abstract}

KEYWORDS: Candida guilliermondii; Non-albicans Candida species; Candidaemia; Candidiasis; Peritonitis; Oesophagitis; AIDS.

\section{INTRODUCTION}

The incidence of invasive infections caused by Candida spp. has notably increased within the past two decades ${ }^{37}$. In addition, an increment has been observed in the proportion of infections caused by species other than Candida albicans, mainly Candida glabrata. The emergence of non-Candida albicans species is a major concern, since some of these species may be highly resistant to antifungals, particularly C. glabrata, C. krusei, C. lusitaniae, and C. guilliermondii. Contrasting to what occurs in North America and Europe, C. parapsilosis, and $C$. tropicalis are - at least at the moment - responsible for the vast majority of non-Candida albicans infections in Brazil1 ${ }^{1,12,35,36}$.

Candida guilliermondii is a component of human microbiota, and is uncommonly isolated from patients as a pathogen. Owing to their lower frequency, infections caused by $C$. guilliermondii are relatively less studied, in comparison to infections caused by other Candida species. The aim of this study was to provide clinical and epidemiological data for patients who had the diagnosis of $C$. guilliermondii infection in our medical centre during a 6-year period.

\section{PATIENTS AND METHODS}

Santa Casa Complexo Hospitalar is a 1,200-bed Brazilian teaching hospital that provides tertiary care. The records of the Mycology Laboratory were reviewed from October 1997 to October 2003, attempting to identify positive cultures for $C$. guilliermondii. Clinical records of these patients were checked.

Samples processing was performed according to standard mycological techniques. After examination for chlamydospore production positive strains at germ tubes test were considered to be Candida albicans. No additional test was performed for the differentiation of $C$. albicans and $C$. dubliniensis. Negative strains at germ tubes tests were identified at species level using kit ID 32C (BioMérieux, France). Candidaemia was diagnosed when a peripheral positive blood culture was temporally related to signs and symptoms. Histopathologic or cytopathologic examination showing $C$. guilliermondii from specimens of needle aspiration or biopsy, excluding mucous membranes, were considered evidence of invasive infection as well as a positive culture result on a sample obtained by sterile procedure from normally sterile site $^{2}$. Patients considered only colonised by $C$. guilliermondii were not included in this study.

\section{RESULTS}

From October 1997 to October 2003 C. guilliermondii was isolated from clinical samples obtained from 11 patients. However, three patients were excluded from the study because the isolation of the yeast represented colonisation. The first of these excluded patients had AIDS and $C$. guilliermondii isolated from the pericardial fluid, in the absence of any inflammatory process in the pericardium. The next two patients 
were liver transplant recipients: one had a single positive urine culture, in the presence of a urinary catheter, and the other had a positive culture from a colon biopsy in which no fungal invasion was observed at histopathology. These three patients discharged with no antifungal treatment. Thus, eight cases were actually included in the study.

Specimens were obtained from blood $(n=5)$, ascitis fluid $(n=2)$, and oesophagus biopsy $(n=1)$. Most patients were male $(62.8 \%)$ and median age was 29.8 years-old (range, 19 days to 73 years-old). Three patients $(37.5 \%)$ had a major immunosuppressed condition, including solid organ transplantation $(\mathrm{n}=1)$, AIDS $(\mathrm{n}=1)$, and leukaemia $(\mathrm{n}=$ 1). Previous use of antibiotics occurred in $87.5 \%$ of cases $(n=7)$. Invasive medical procedures included central venous catheter $(50.0 \%)$, abdominal surgery $(25.0 \%)$, peritoneal dialysis $(50.0 \%)$, mechanical ventilation $(25.0 \%)$, and parenteral nutrition $(12.5 \%)$. There was no report of previous polyene use for any of these patients. These eight patients are presented below. Table 1 summarizes relevant aspects for these cases. All patients were treated with antifungals, but one. Overall mortality was $12.8 \%$.

During the period of study, a total of 190 cases of candidaemia were documented in our medical centre. C. guilliermondii accounted for $2.6 \%$ of these cases. While the overall mortality for patients with candidaemia was $48.9 \%$ (60.0\% for patients infected by C. albicans), none of the five patients with candidaemia caused by $C$. guilliermondii died. Apart from that, no difference was observed amongst patients with candidaemia caused by $C$. guilliermondii or other Candida species regarding demographic features, underlying diseases, and frequency of invasive medical procedures, antimicrobials use, and other predisposing conditions to candidaemia. In addition, during the period of study there were 864 positive cultures for Candida obtained from oesophagus samples, and 72 positive cultures from dialysis fluid. Thus, C. guilliermondii was the aetiology of $0.1 \%$ and $2.8 \%$ of oesophagitis and dialysis-associated peritonitis caused by Candida species, respectively.

\section{PATIENTS}

Patient 1. A full-term female neonate was submitted to gastroschisis correction. The postoperative course was complicated with haemodynamic instability, and the patient was treated with mechanical ventilation and parenteral nutrition. Therapy also included multiple empiric antibiotic courses for sepsis, including ampicillin, gentamicin, vancomycin, cefotaxime, amikacin, and metronidazole. Twenty days after her birth, $C$. guilliermondii grew in blood culture. She completed 25 days of amphotericin B and was discharged from the hospital.

Patient 2. A 45 year-old man was admitted to the hospital for secondary pulmonary hypertension attributable to recurrent lung embolism. Bacteraemia due to K. pneumoniae occurred after pulmonary arteriography and the patient received a 14-day course of cefuroxime for this catheter-related infection. Fever relapsed and C. guilliermondii was isolated from blood culture. Evolution was favourable with 14 days of amphotericin B.

Patient 3. A 6-year-old boy with acute lymphocytic leukaemia developed fever after chemotherapy. The patient was not neutropenic and maintained fever despite treatment with amoxicillin-clavulanate. Blood culture yielded Stenotrophomonas maltophilia and $C$. guilliermondii. A port-a-cath infected with S. maltophilia was removed. The patient was discharged after 13 days of intravenous trimethoprimsulfamethoxazole and amphotericin B.

Patient 4. A 73-year-old woman developed lung embolism and acute cor pulmonale after elective electric cardioversion for intermittent atrial flutter. She received 14 day of cefuroxime for nosocomial pneumonia. Her blood was taken out for culture due to leukocytosis, hypothermia and hypotension, and one out of three samples yielded $C$. guilliermondii. The patient became asymptomatic and received no antifungal therapy.

Patient 5. A 45-year-old immunocompetent man was admitted for elective cholecystectomy. Cellulitis occurred at peripheral venous site associated with fever, chills, and hypotension. Three blood cultures were positive for $K$. pneumoniae and two were positive for $C$. guilliermondii. The peripheral catheter was removed but not sent to culture. The patient was treated with ampicillin-sulbactam and fluconazole for seven days, and he was discharged 10 days after the positive blood cultures for Candida were taken.

Patient 6. A 1-year-old boy with chronic renal failure was in treatment with continuous ambulatory peritoneal dialysis (CAPD). $\mathrm{He}$ was admitted to the hospital due to fever, abdominal pain, and vomit.

Table 1

Characteristics of the eight patients with infection caused by Candida guilliermondii

\begin{tabular}{lllll}
\hline Case & Sex, Age & Underlying conditions & Origin of specimen & Antifungal treatment, duration \\
\hline 1 & F, 19d & Abdominal surgery (gastroschisis) & Blood & AmB $1.1 \mathrm{mg} / \mathrm{kg} / \mathrm{d}, 25 \mathrm{days}$ \\
2 & $\mathrm{M}, 45 \mathrm{y}$ & Secondary pulmonary hypertension & Blood & AmB $1.0 \mathrm{mg} / \mathrm{kg} / \mathrm{d}, 14 \mathrm{days}$ \\
3 & $\mathrm{M}, 6 \mathrm{y}$ & Acute lymphocytic leukaemia & Blood & $\mathrm{AmB} 0.9 \mathrm{mg} / \mathrm{kg} / \mathrm{d}, 13 \mathrm{days}$ \\
4 & $\mathrm{~F}, 73 \mathrm{y}$ & Supraventricular arrhythmia & Blood & No specific treatment \\
5 & $\mathrm{M}, 45 \mathrm{y}$ & Cholecystectomy & Blood & $\mathrm{Flu} 6.7 \mathrm{mg} / \mathrm{kg} / \mathrm{d}, 7 \mathrm{days}$ \\
6 & M, 1y & Peritoneal dialysis & Ascitis fluid & $\mathrm{Flu} 4.2 \mathrm{mg} / \mathrm{kg} / \mathrm{d}, 10 \mathrm{days}$ \\
7 & F, 21y & Immunosuppressive therapy & Ascitis fluid & AmB $0.5 \mathrm{mg} / \mathrm{kg} / \mathrm{d}, 6 \mathrm{days}$, then \\
& & Peritoneal dialysis & & Flu $4 \mathrm{mg} / \mathrm{kg} / \mathrm{d}, 10 \mathrm{days}$ \\
\hline
\end{tabular}

$\mathrm{M}=$ Male $; \mathrm{F}=$ Female $; \mathrm{AmB}=$ Amphotericin B desoxycholate; Flu = Fluconazole. 
Dialysis fluid was muddy, and C. guilliermondii grew in a sample taken from CAPD bag. The Tenckhoff catheter was removed and then reinserted after 10 days of fluconazole. Culture of the previous catheter yielded Candida spp., and the patient was discharged in good health.

Patient 7. A 21-year-old woman on CAPD was admitted due to fever, vomits, and abdominal pain. She had been submitted to renal transplantation five years before. Graft loss occurred due to rejection and the patient was on prednisone (5 mg daily) and cyclosporine (50 $\mathrm{mg}$ daily). At admission, cephalothin and amikacin were empirically started, and culture taken from CAPD bag revealed pure growth of $C$. guilliermondii. After six days of amphotericin B, the catheter was replaced, and antimicrobial therapy subsequently changed to fluconazole and cephalothin. Culture of catheter yielded Candida spp.. The patient was discharged after treatment with cefepime for nosocomial pneumonia.

Patient 8. A 38-year-old male patient with AIDS (CD4 count 46 cells $/ \mathrm{mm}^{3}$ ), idiopathic dilated myocardiopathy, and severe systolic dysfunction was admitted for pneumonia. He was treated with ciprofloxacin. Fluconazole was prescribed to treat dysphagia associated with oral candidosis, and it was further suspended due to hepatotoxicity. Upper gastrointestinal endoscopy showed oesophageal candidosis with C. guilliermondii in culture. The patient died due to cardiac failure.

\section{DISCUSSION}

Candida guilliermondii seems to be one of the least virulent amongst Candida species $^{3,7,18,22}$. In a study using an immunocompetent mouse model ${ }^{3}$, eight Candida species could be divided into three virulence groups of decreasing pathogenicity: (1) C. albicans and $C$. tropicalis; (2) C. glabrata, C. lusitaniae and C. kefyr; and (3) C. parapsilosis, C. krusei and C. guilliermondii. This hierarchic classification was based on mortality, number of kidneys infected, clearance of - or established infection in kidneys, CFU counts in tissue, capacity to involve eyes, and histopathological findings in kidneys. $C$. guilliermondii was the species with the lowest pathogenic potential in this study. In another study ${ }^{21}$, no mortality was observed in animals persistently infected with $C$. guilliermondii. This was associated with the organism's failure to cause diffuse involvement of the renal parenchyma, to produce pseudomycelia, or to invade the renal tubular lumen. Differently from mice infected with $C$. parapsilosis, corticosteroids neither induced progressive infection nor delayed tissue clearance in C. guilliermondii infections ${ }^{21}$.

In concordance with its low pathogenicity, $C$. guilliermondii is an uncommon aetiology of invasive candidosis, accounting for $0-3 \%$ of candidaemias in Latin America and Brazil1,10-12,19,20,35,36,42. Few Brazilian studies have documented higher percentages such as $9 \%$ to $14 \%{ }^{13,29,32,33}$. These results should be seen with caution. Five cases of candidaemia were presented here (patients 1-5) and most of these patients had a favourable response to treatment with amphotericin $B$ desochycolate. One of these patients had a good clinical evolution despite the absence of antifungal therapy (case 4). As this immunocompetent patient had leukocytosis, hypothermia and hypotension at the time the positive blood culture for Candida was taken, we considered him as truly infected, not colonised. Transitory candidaemia may have occurred.
At the moment, no specific risk factor has been described for $C$. guilliermondii infections. Furthermore, we found no difference in risk factors for candidaemia amongst these five patients with candidaemia caused by $C$. guilliermondii and 185 patients with candidaemia caused by other species seen in the same period in our medical centre. Of importance, the limited number of patients included in this study does not permit any small differences between these groups to be revealed.

A nosocomial outbreak of $C$. guilliermondii fungaemia was recently reported involving five patients admitted to a general surgery unit of a tertiary care hospital over a 2 -week period ${ }^{28}$. All clinical isolates of $C$. guilliermondii were identical when typed by random amplified polymorphic DNA (RAPD). The evidence for clonality associated with the fact that at least three of five cases were associated with central venous catheters led to the conclusion that cross-contamination between patients and staff probably occurred. This may have important consequences in terms of infection control policies. A pseudo-outbreak of $C$. guilliermondii fungaemia due to contamination of heparin vials in a neonatal intensive care unit was also reported ${ }^{49}$.

Two cases of $C$. guilliermondii peritonitis were presented here, associated with an infected peritoneal dialysis catheter (patients 6 and 7). Both patients had a good clinical response after antifungal therapy and catheter removal. Fungal peritonitis occurs in 2-10\% of peritoneal dialysis patients with clinical presentation similar to bacterial infection (which is more frequent) ${ }^{6}$. C. guilliermondii peritonitis is a very uncommon disease ${ }^{5}$. In a recent review of 46 cases of fungal peritonitis on peritoneal dialysis patients, only four cases of peritonitis due to $C$. guilliermondii were reported ${ }^{6}$. Another case was reported in a series of 15 patients with fungal peritonitis in patients on CAPD. That particular strain was resistant to itraconazole ${ }^{25}$. Other case was reported in India amongst 28 episodes of fungal peritonitis ${ }^{40}$.

Candidosis is the most common cause of oropharyngeal disease in HIV-infected patients and it is usually caused by $C$. albicans. $C$. guilliermondii oesophagitis is not common ${ }^{31,44,47}$ and it was not found in a multicentre Brazilian study of 130 patients with AIDS $^{43}$. Patient 11 reported in our study had the typical clinical presentation of Candida oesophagitis. These manifestations are common to all Candida species, and there is no particular finding which could suggest $C$. guilliermondii as the aetiologic agent. Oral infections have been reported in diabetic patients $^{16}$, and in patients with denture stomatitis ${ }^{8,14,16,17}$. In one report, an immunocompentent patient presented with a dento-alveolar abscess in a polymicrobial infection in which Candida guilliermondii was a copathogen together with two other oral bacteria ${ }^{30}$. Oral colonisation has also been described in immunocompentent individuals ${ }^{41,48}$, patients with cancer $^{4,45}$, as well as in those treated with oral inhaled corticosteroids ${ }^{23}$.

Assuming that $C$. guilliermondii infections are uncommon and associated with a low virulence, where do their importance reside? The answer is antifungal resistance. Together with $C$. tropicalis and $C$. lusitaniae, $C$. guilliermondii is one of the main Candida species where polyene resistance has occurred ${ }^{15,24,39}$. Additionally, isolates of $C$. guilliermondii frequently demonstrate higher MICs to other antifungal drugs, including echinocandins ${ }^{34}$ and azoles ${ }^{9,38,46}$. This may be associated with therapeutic failures and sometimes deaths. Although susceptibility tests were not performed in the current study, no clinical failure occurred in patients treated with amphotericin B. 
In conclusion, this study provided clinical data for eight patients infected with $C$. guilliermondii. Their characteristics were similar to what is expected for Candida infections, a frequent association with antibiotics and catheters. For some patients, the recovery of $C$. guilliermondii from clinical specimens represented colonisation. Aseptic technique should be rigorously performed during the process of sampling to avoid mistakes in the interpretation of a positive culture. Mortality associated with $C$. guilliermondii was very low in comparison with mortality observed for other Candida species. No clinical failure occurred in patients treated with amphotericin B desochycolate. Based on previous reports revealing resistance to several antifungal drugs including polyenes, echinocandins, and azoles - routine susceptibility tests have been suggested for $C$. guilliermondii infections.

\section{RESUMO}

\section{Candida guilliermondii como agente de candidose}

Candida guilliermondii é um dos componentes da microbiota humana e infecções associadas com esta levedura têm sido incomuns, o que pode ser atribuído a sua baixa patogenicidade. O objetivo deste trabalho foi documentar aspectos clínico-epidemiológicos em pacientes que tiveram $C$. guilliermondii isolada a partir de amostras biológicas. O estudo foi conduzido na Santa Casa Complexo Hospitalar, Brasil. Durante outubro de 1997 e outubro de 2003, C. guilliermondii foi isolada de 11 pacientes, três dos quais foram excluídos por se apresentarem apenas colonizados. Espécimes clínicos corresponderam a sangue $(\mathrm{n}=5)$, líquido de ascite $(\mathrm{n}=2)$ e biópsia de esôfago $(\mathrm{n}=1)$. Três pacientes eram imunodeprimidos, incluindo transplante de órgãos sólidos, SIDA e leucemia. Uso prévio de antimicrobianos ocorreu em $87,5 \%$ dos casos. Procedimentos médicos invasivos incluíram o uso de cateteres venosos centrais $(50,0 \%)$, cirurgia abdominal $(25,0 \%)$ e diálise peritonial $(50,0 \%)$. Testes de susceptibilidade não foram realizados. Embora fatores de risco para candidemia tenham sido semelhantes entre pacientes infectados por $C$. guilliermondii ou outras espécies de Candida, a mortalidade associada com C. guilliermondii foi significativamente menor.

\section{REFERENCES}

1. ANTUnes, A.G.V.; PASQUAlotTo, A.C.; DiAZ M.C.; d'AZEVEDo, P.A. \& SEVERO, L.C. - Candidemia in a Brazilian tertiary care hospital: species distribution and antifungal susceptibility patterns. Rev. Inst. Med. trop. S. Paulo, 46: 239-241, 2004.

2. ASCIOGLU, S.; REX, J.H.; DE PAUW, B. et al. - Defining opportunistic invasive fungal infections in immunocompromised patients with cancer and hematopoietic stem cell transplants: an international consensus. Clin. infect. Dis., 34: 7-14, 2002.

3. ARENDRUP, M.; HORN, T. \& FRIMODT-MOLLER N. - In vivo pathogenicity of eight medically relevant Candida species in an animal model. Infection, 30: 286-291, 2002.

4. BALL, K.; SWEENEY, M.P.; BAXTER, W.P. \& BAGG, J. - Fluconazole sensitivities of Candida species isolated from the mouths of terminally ill cancer patients. Amer. J. Hosp. palliat. Care, 15: 315-319, 1998.

5. BAYER, A.S.; BLUMENKRANTZ, M.J.; MONTGOMERIE, J.Z. et al. - Candida peritonitis. Report of 22 cases and review of the English literature. Amer. J. Med., 61: 832-840, 1976.
6. BIBASHI, E.; MEMMOS, D.; KOKOLINA, E. et al. - Fungal peritonitis complicating peritoneal dialysis during an 11-year period: report of 46 cases. Clin. infect. Dis., 36: 927-931, 2003.

7. BISTONI, F.; VECCHIARELLI, A.; CENCI, E. et al. - A comparison of experimental pathogenicity of Candida species in cyclophosphamide-immunodepressed mice. Sabouraudia, 22: 409-418, 1984

8. BUDTZ-JÖRGENSEN, E.; STENDERUP, A. \& GRABOWSKI, M. - An epidemiologic study of yeasts in elderly denture wearers. Community Dent. oral Epidem., 3: 115-119, 1975.

9. BULMER, G.S.; MARQUEZ, M.L.; CO-BARCELONA, L. \& FROMTLING, R.A. Yeasts and fluconazole susceptibility in the Philippines. Mycopathologia, 146: $117-$ $120,1999$.

10. COLOMBO, A.L. \& GUIMARÃES, T. - Epidemiology of hematogenous infections due to Candida spp. Rev. Soc. bras. Med. trop., 36: 599-607, 2003.

11. COLOMBO, A.L.; NAKAGAWA, Z.; VALDETARO, F. et al. - Susceptibility profile of 200 bloodstream isolates of Candida spp. collected from Brazilian tertiary care hospitals. Med. Mycol., 41: 235-239, 2003.

12. COLOMBO, A.L.; NUCCI, M.; SALOMÃO, R. et al. - High rate of non-albicans candidemia in Brazilian tertiary care hospitals. Diagn. Microbiol. infect. Dis., 34: 281-286, 1999.

13. COSTA, S.F.; MARINHO, I.; ARAÚJO, E.A. et al. - Nosocomial fungaemia: a 2-year prospective study. J. Hosp. Infect., 45: 69-72, 2000.

14. CROSS, L.J.; WILLIAMS, D.W.; SWEENEY, C.P. et al. - Evaluation of the recurrence of denture stomatitis and Candida colonization in a small group of patients who received itraconazole. Oral Surg. oral Med. oral Path. oral Radiol. Endod., 97: 351-358, 2004.

15. DICK, J.D.; ROSENGARD, B.R.; MERZ, W.G. et al. - Fatal disseminated candidiasis due to amphotericin-B-resistant Candida guilliermondii. Ann. intern. Med., 102: 67-68, 1985.

16. DORKO, E.; BARANOVA, Z.; JENCA, A. et al. - Diabetes mellitus and candidiases. Folia Microbiol. (Praha), 50: 255-261, 2005.

17. DORKO, E.; JENCA, A.; PILIPCINEC, E. et al. - Candida-associated denture stomatitis. Folia Microbiol. (Praha), 46: 443-446, 2001.

18. EDWARDS Jr., J.E.; MONTGOMERIE, J.Z.; ISHIDA, K.; MORRISON, J.O. \& GUZE, L.B. - Experimental hematogenous endophthalmitis due to Candida: species variation in ocular pathogenicity. J. infect. Dis., 135: 294-297, 1977.

19. GODOY, P.; TIRABOSCHI, I.N.; SEVERO, L.C. et al. - Species distribution and antifungal susceptibility profile of Candida spp. bloodstream isolates from Latin American Hospitals. Mem. Inst. Oswaldo Cruz, 98: 401-405, 2003.

20. GOLDANI, L.Z. \& MARIO, P.S.S. - Candida tropicalis fungemia in a tertiary care hospital. J. Infect., 46: 155-160, 2003.

21. GOLDSTEIN, E.; GRIECO, M.H.; FINKEL, G. \& LOURIA, D.B. - Studies on the pathogenesis of experimental Candida parapsilosis and Candida guilliermondii infections in mice. J. infect. Dis., 115: 293-302, 1965.

22. HOWLETT, J.A. - The infection of rat tongue mucosa in vitro with five species of Candida. J. med. Microbiol., 9: 309-316, 1976.

23. KOMIYAMA, E.Y.; RIBEIRO, P.M.; JUNQUEIRA, J.C.; KOGA-ITO, C.Y. \& JORGE, A.O. - Prevalence of yeasts in the oral cavity of children treated with inhaled corticosteroids. Pesq. odont. bras., 18: 197-201, 2004.

24. KOVACICOVA, G.; HANZEN, J.; PISARCIKOVA, M. et al - Nosocomial fungemia due to amphotericin B-resistant Candida spp. in three pediatric patients after previous neurosurgery for brain tumors. J. Infect. Chemother., 7: 45-48, 2001. 
25. MANZANO-GAYOSSO, P.; HERNANDEZ-HERNANDEZ, F.; MENDEZ-TOVAR, L J GONZALEZ-MONROY, J. \& LOPEZ-MARTINEZ R. - Fungal peritonitis in 15 patients on continuous ambulatory peritoneal dialysis (CAPD). Mycoses, 46: 425$429,2003$.

26. MARDANI, M.; HANNA, H.A.; GIRGAWY, E. \& RAAD, I. - Nosocomial Candida guilliermondii fungemia in cancer patients. Infect. Control Hosp. Epidem., 21: 336-337, 2000.

27. MARQUES, S.R. - Candidemias: aspectos preditivos da infecção em crianças hospitalizadas. São Paulo, 2002. (Dissertação de Mestrado - Coordenação dos Institutos de Pequisa da Secretaria da Saúde do Estado de São Paulo).

28. MASALA, L.; LUZZATI, R.; MACCACARO, L. et al. - Nosocomial cluster of Candida guillermondii fungemia in surgical patients. Europ. J. clin. Microbiol. infect. Dis., 22: 686-688, 2003.

29. MATSUMOTO, F.E.; GANDRA, R.F.; RUIZ, L.S. et al. - Yeasts isolated from blood and catheter in children from a public hospital of São Paulo, Brazil. Mycopathologia, 154: 63-69, 2002.

30. McMANNERS, J. \& SAMARANAYAKE, L.P. - Suppurative oral candidosis. Review of the literature and report of a case. Int. J. oral maxillofac. Surg., 19: 257-259, 1990

31. MELO, N.R.; TAGUCHI, H.; JORGE, J. et al. - Oral Candida flora from Brazilian human immunodeficiency virus-infected patients in the highly active antiretroviral therapy era. Mem. Inst. Oswaldo Cruz, 99: 425-431, 2004.

32. NUCCI, M.; SILVEIRA, M.I.; SPECTOR, N. et al. - Fungemia in cancer patients in Brazil: predominance of non-albicans species. Mycopathologia (Den Haag), 141: 65-68, 1998.

33. PAIS, L.P.F. - Avaliação do comportamento epidemiológico e de práticas terapêuticas nos episódios de candidemia registrados em dois hospitais universitários no período de 1994 a 1998. São Paulo, 1999. (Dissertação de Mestrado - Universidade Federal de São Paulo).

34. PAPPAS, P.G.; REX, J.H.; SOBEL, J.D. et al. - Guidelines for treatment of candidiasis. Clin. infect. Dis., 38: 161-189, 2004.

35. PASQUALOTTO, A.C.; NEDEL, W.L.; MACHADO, T.S. \& SEVERO, L.C. - Risk factors and outcome for nosocomial breakthrough candidaemia. J. Infect., 52: 216-222, 2006.

36. PASQUALOTTO, A.C.; NEDEL, W.L.; MACHADO, T.S. \& SEVERO, L.C. - A comparative study of risk factors and outcome among outpatient-acquired and nosocomial candidaemia. J. Hosp. Infect., 60: 129-134, 2005.

37. PFALLER, M.A.; JONES, R.N.; MESSER, S.A.; EDMOND, M.B. \& WENZEL, R.P. National surveillance of nosocomial blood stream infection due to Candida albicans: frequency of occurrence and antifungal susceptibility in the SCOPE Program. Diagn. Microbiol. infect. Dis., 31: 327-332, 1998
38. PFALLER, M.A.; DIEKEMA, D.J.; MESSER, S.A. et al. - In vitro susceptibilities of rare Candida bloodstream isolates to ravuconazole and three comparative antifungal agents. Diagn. Microbiol. infect. Dis., 48: 101-105, 2004.

39. POWDERLY, W.G.; KOBAYASHI, G.S.; HERZIG, G.P. \& MEDOFF, G. - Amphotericin B-resistant yeast infection in severely immunocompromised patients. Amer. J. Med., 84: $826-832,1988$.

40. PRASAD, K.N.; PRASAD, N.; GUPTA, A. et al. - Fungal peritonitis in patients on continuous ambulatory peritoneal dialysis: a single centre Indian experience. J. Infect., 48: 96-101, 2004.

41. RASOOL, S.; SIAR, C.H. \& NG, K.P. - Oral candidal species among smokers and nonsmokers. J. Coll. Phycns Surg. Pak., 15: 679-682, 2005

42. ROSAS, R.C.; SALOMÃO, R.; DA MATTA, D.A. et al. - Bloodstream infections in latestage acquired immunodeficiency syndrome patients evaluated by a lysis centrifugation system. Mem. Inst. Oswaldo Cruz, 98: 529-532, 2003.

43. SANT'ANA, P.L.; MILAN, E.P.; MARTINEZ, R. et al. - Multicenter Brazilian study of oral Candida species isolated from Aids patients. Mem. Inst. Oswaldo Cruz, 97: 253-257, 2002

44. TACCONELLI, E.; BERTAGNOLIO, S.; POSTERARO, B. et al. - Azole susceptibility patterns and genetic relationship among oral Candida strains isolated in the era of highly active antiretroviral therapy. J. acquir. immune Defic. Syndr., 31: 38-44, 2002.

45. TEKELI, A.; DOLAPCI, I.; CESUR, S.; TEKELI, E. \& ICLI, F. - Candida dubliniensis studies and isolation of Candida types in oropharyngeal specimens from oncologic patients. Mikrobiyol. Bul., 36: 57-63, 2002.

46. TIETZ, H.J.; CZAIKA, V. \& STERRY, W. - Case report. Osteomyelitis caused by high resistant Candida guilliermondii. Mycoses, 42: 577-580, 1999.

47. TUMBARELlO, M.; CALDAROLA, G.; TACCONELLI, E. et al - Analysis of the risk factors associated with the emergence of azole resistant oral candidosis in the course of HIV infection. J. Antimicrob. Chemother., 38: 691-699, 1996

48. VANDENBUSSCHE, M. \& SWINNE, D. - Yeasts oral carriage in denture wearers Mykosen, 27: 431-435, 1984.

49. YAGUPSKY, P.; DAGAN, R.; CHIPMAN, M. et al. - Pseudooutbreak of Candida guilliermondii fungemia in a neonatal intensive care unit. Pediat. infect. Dis. J., 10: 928-932, 1991.

Received: 6 September 2005

Accepted: 9 January 2006 